\title{
PHẪU THUẬT NỘI SOI ĐIỀU TRI BỆNH U NẤM PHỔI ASPERGILOMA
}

\section{TÓM TẮT}

Trong thời gian từ $1 / 2012$ dến $12 / 2017$, chúng tôi đã PTNSLN điều trị u nấm phổi cho 18 bệnh nhân. Giới: 5 nữ, 13 nam. Tuổi trung bình là 46.5. Trong đó: 15 bệnh nhân là u nấm đơn giản, 3 bệnh nhân u nấm phức tạp. PTNS cắt thùy phổi 14 bệnh nhân, 2 bệnh nhân phải chuyển mổ mở. Tất cả bệnh nhân ra viện tốt, 2 bệnh nhân dò khí sau mổ. PTNS là phương pháp phẫu thuật an toàn, có nhiều ưu điểm, có thể chỉ định trong bệnh u nấm phổi, chủ yếu là u nấm đơn giản. Đối với u nấm phức tạp, phẫu thuật mổ mở vẫn còn lá phương pháp được lựa chọn, PTNS chỉ nên được tiến hành khi PTV có đủ kinh nghiệm và kỹ năng cần thiết để tiến hành PTNS.

Tù khóa: PTNS, u nấm phổi

SUMMARY

VIDEO ASSISTED THORACOSCOPIC SURGERY (VATS) FOR PULMONARY ASPERGILLOMA

During 5 years (1/2012-12/2017), there were 18 pulmonary aspergilloma patients were operated. Males: 13, females: 5. Mean age: 46.5. Almost patients are simple aspergilloma (15 patients). 14 patients were thoracoscopic lobectomy.

18 patients were discharged safely. 2 patients: convert to thoracotomy due to adhesion of pulomonary tissue and lymph nodes to pulmonary artery. VATS is good and safety procedure for simple pulmonary aspergilloma .

Key word: VATS, pulmonary aspergilloma.

\section{I. ĐẶT VẤN ĐỀ}

Phẫu thuật đóng một vai trò quan trọng trong điều trị u nấm phổi do aspergilus, đặc biệt đối với những bệnh nhân ho ra máu lượng nhiều.
Nguyễn Hoàng Bình", Vũ Hũu Vĩnh ${ }^{*}$

Với sự phát triển của các dụng cụ, phương tiện nội soi lồng ngực, gây mê hồi sức, phẫu thuật nội soi lồng ngực (PTNSLN) đã được ứng dụng trong điều trị ngoại khoa u nấm phổi thay thế cho mổ mở trong một số trường hợp. PTNS cắt thùy phổi đã cho thấy có thể thực hiện an toàn có hiệu quả và có nhiều ưu điểm như: giảm đau sau mổ, ít suy giảm chức năng hô hấp sau mổ, bênh nhân hồi phục sớm sau phẫu thuật. Tuy nhiên các báo cáo về PTNS điều trị u nấm phổi vẫn còn nhiều tranh cãi, về chỉ định phẫu thuật, phương pháp can thiệp cũng nhưu kết quả.

Trong chỉ định để PTNS cắt u nấm phổi, vấn đề đặt ra ở đây là phổi thường dính, hạch tăng sinh phản ứng lớn, dính, tăng sinh mạch máu, làm tăng nguy cơ chảy máu, nguy cơ thất bại của phẫu thuật.[5]

Vì vậy chúng tôi tiến hành nghiên cứu này để đánh giá những chỉ định phẫu thuật, những giới hạn của PTNS cắt $\mathrm{u}$ nấm phổi và rút ra một số kinh nghiệm bước đầu về phương pháp phẫu thuật, sự an toàn, kết quả sớm.

\section{II. ĐỐI TƯợNG VÀ PHƯƠNG PHÁP}

\section{1. Đối tượng:}

Tất cả bệnh nhân bệnh u nấm phổi thất bại điều trị nội, ho ra máu, cần phân biệt với u ác tính, có chỉ định điều trị ngoại khoa phẫu thuật cắt thùy phổi, đủ điều kiện phẫu thuật và gây mê nội khí quản một phổi.

Loại trừ: bệnh nhân được chẩn đoán u nấm phổi/ ung thư phổi.

2.2. Phương pháp nghiên cứu: Hồi cứu mô tả

* Khoa Ngoại Lồng ngực Bệnh viện Chợ Rây

Ngưòi chịu trách nhiệm khoa học: TS. Vũ Hũu Vĩnh

Ngày nhận bài: 01/05/2018 - Ngày Cho Phép Đăng: 20/05/2018

Phản Biện Khoa học: GS.TS. Bùi Đức Phú

PGS.TS. Đặng Ngọc Hùng 


\section{Phưong pháp:}

Bệnh nhân được chụp X quang phổi, Chụp cắt lớp (CT Scans), nội soi phế quản, chức năng phổi, các xét nghiệm tiền phẫu. Bệnh nhân được chia làm hai nhóm dựa trên $\mathrm{CT}$ Scans theo Belcher và Plummer:

U nấm đơn giản: Thành hang nấm mỏng $<3 \mathrm{~mm}$, không có tổn thương nhu mô phổi xung quanh.

U nấm phức tạp: Thành hang nấm dày $>$ $3 \mathrm{~mm}$, có tổn thương nhu mô phổi xung quanh.

\section{Phuơng pháp phẫu thuật:}

Bệnh nhân được gây mê nội khí quản 1 phổi, nằm nghiêng. Đặt 3 trocar qua đường rạch da khoảng $1 \mathrm{~cm}$ : trong đó 1 trocar cho camera, khoang liên sườn 6 , nách giữa, 1 trocar cho dụng cụ kéo phổi khoảng liên sườn, 1 trocar để thao tác, thường được mở rộng $3-4 \mathrm{~cm}$ để thao tác khi cần thiết cũng như lấy phổi ra.

Sinh thiết lạnh trước nếu không có giải phẫu bệnh lý trước mổ. Dùng stapler cắt phế quản, tĩnh mạch, động mạch riêng lẻ. Lấy bệnh phẩm với túi nylon để tránh mô tiếp xúc thành ngực gây nhiễm trùng

\section{Ghi nhận}

Thời gian phẫu thuật, lượng máu mất trong mổ, thời gian dẫn lưu phổi, thời gian nằm viện sau mổ. Đánh giá các biến chứng: dò khí, chảy máu, viêm phổi...

Đánh giá lí do chuyển mổ mở. Định nghĩa mổ mở là khi phẫu thuật đã được tiến hành bóc tách, cắt động mạch hay tĩnh mạch sau đó chuyển mổ mở. Loại trừ những trường hợp phải chuyển mổ mở ngay từ đầu do gây mê thất bại hay do phổi quá dính không phẫu thuật được.

Bệnh nhân được theo dõi trong vòng 1 tháng sau phẫu thuật. Đánh giá kết quả, phân tích nguyên nhân biến chứng, tử vong.

\section{KẾT QUẢ}

18 bệnh nhân bệnh u nấm phổi được PTNS trong thời gian từ $1 / 2012-12 / 2017$ tại khoa Ngoại Lồng ngực, Bệnh viện Chợ Rẫy. Tất cả bệnh nhân này đều có chỉ định cắt thùy phổi, sau khi thất bại điều trị nội hay ho ra máu, viêm nhiễm tái đi tái lại nhiều lần, sang thương khu trú một thùy phổi, không lan tỏa toàn phổi.

- Nam: 13 (72.2\%) Nữ: 5 (27.8\%)

- Tuổi: lớn nhất: 61 tuổi, nhỏ nhất: 32 tuổi trung bình: 46,5

- Triệu chứng lâm sàng:

Ho và ho ra máu: 14 bệnh nhân (77.7\%) có 1 bệnh nhân được bơm tắc trước phẫu thuật; Đau ngực: 5 bệnh nhân (27.7 \%)

Viêm nhiễm (phổi, phế quản) tái đi tái lại: 4 bệnh nhân (22.2\%)

U trong thùy phổi: 18 bệnh nhân

Vị trí u phổi

\begin{tabular}{|l|c|c|}
\hline Vị trí u nấm & Bệnh nhân & $\mathbf{\%}$ \\
\hline Thùy trên phổi phải & 12 & 66.7 \\
\hline Thùy giữa phối phải & 0 & 0 \\
\hline Thùy dưới phối phải & 1 & 5.5 \\
\hline Thùy trên phổi trái & 4 & 22.3 \\
\hline Thùy dưới phối trái & 1 & 5.5 \\
\hline Tổng số & $\mathbf{1 8}$ & $\mathbf{1 0 0}$ \\
\hline
\end{tabular}

Tính chất u nấm

\begin{tabular}{|l|c|c|}
\hline U nấm & Bệnh nhân & $\mathbf{\%}$ \\
\hline U nấm đơn giản & 15 & 83.3 \\
\hline U nấm phức tạp & 3 & 16.7 \\
\hline Tổng số & $\mathbf{1 8}$ & $\mathbf{1 0 0}$ \\
\hline
\end{tabular}

Bệnh đi kèm

\begin{tabular}{|l|c|c|}
\hline Bệnh đi kèm & Bệnh nhân & $\mathbf{\%}$ \\
\hline Tiền căn lao phổi: & 3 & 16.7 \\
\hline Dãn phế quản & 1 & 5.5 \\
\hline Viêm phồi & 2 & 11.1 \\
\hline Tiểu đường & 5 & 27.8 \\
\hline
\end{tabular}


- Phương pháp phẫu thuật

\begin{tabular}{|l|c|c|}
\hline PP PT & Bệnh nhân & $\mathbf{\%}$ \\
\hline Cắt thùy phổi & 14 & 77.7 \\
\hline Cắt Wegde & 2 & 11.1 \\
\hline PTNS chuyển mổ mở & 2 & 11.1 \\
\hline Tổng số & $\mathbf{1 8}$ & $\mathbf{1 0 0}$ \\
\hline
\end{tabular}

- Thời gian phẫu thuật: trung bình 3,12 giờ. Lâu nhất: 5 giờ. $\quad$ Nhanh nhất: 2.1 giờ

- Thời gian nằm viện sau mổ: 4.2 ngày. Lâu nhất: 7 ngày. Nhanh nhất: 3 ngày

- Lượng máu mất: Trung bình: $79.6 \mathrm{ml}$. Nhiều nhất: $400 \mathrm{ml}$ Thấp nhất: $50 \mathrm{ml}$

Biến chứng: không ghi nhận biến chứng trầm trọng

\begin{tabular}{|l|c|c|}
\hline Biến chứng & Bệnh nhân & $\mathbf{\%}$ \\
\hline Tràn khí dưới da & 2 & 11.1 \\
\hline Chảy máu vết mồ sau mổ & 1 & 5.5 \\
\hline Dò khí & 2 & 11.1 \\
\hline
\end{tabular}

Chuyển mổ mở: 2 bệnh nhân (11.1\%): 1 do chảy máu từ nhánh động mạch phổi khi bóc tách, 1 do hạch dính vào động mạch không bóc tách được.

\section{BÀN LUẬN}

Những năm đầu thập niên 1990, sau khi Kirby giới thiệu ca PTNS cắt thùy phổi đầu tiên, PTNS cắt thùy phổi bắt đầu được triển khai tại các trung tâm phẫu thuật lồng ngực trên thế giới [6]. U nấm phổi thường được phẫu thuật mổ mở bởi vì bệnh nhân thường phổi dính khoang màng phổi rất nhiều cũng như rãnh liên thùy phổi thường không rõ ràng khi bóc tách mạch máu phổi. Vì vậy bệnh nhân có nguy cơ cao chảy máu khi bóc tách cũng như tổn thương mạch máu phổi. Tuy nhiên, một số bệnh nhân có tổng trạng trước mổ không ổn cho nên PTNS với đường mổ nhỏ sẽ có nhiều ưu điểm hơn cho bệnh nhân [2].

Theo Weber, tất cả bệnh nhân có bệnh phổi lành tính, thất bại điều trị nội khoa, bệnh nhân vẫn còn những triệu chứng như ho, viêm phổi tái đi tái lại, ho ra máu, tôn thương khu trú một thùy, không lan tỏa toàn phổi thì có chỉ định PTNS cắt thùy [1].
Trong nghiên cứu của chúng tôi: các bệnh nhân u nấm phổi có chỉ định ngoại khoa khi bệnh nhân phát hiện có hình ảnh u nấm trên phim kèm theo có triệu chứng ho ra máu hay điều trị nội khoa còn tái phát.

U nấm đơn giản, có thành mỏng $<3 \mathrm{~mm}$, có ít hay không có tổn thương phổi đi kèm, khu trú một thùy, bệnh nhân có triệu chứng ho ra máu. Có 1 bệnh nhân u phổi được cắt không điển hình kết quả sau cùng u nấm phổi.

U nấm phức tạp, có 3 bệnh nhân được PTNS, tu nhiên 2 bệnh nhân phải chuyển mổ mở.

PTNS cắt thùy phổi ở bệnh phổi lành tính thường được các phẫu thuật viên lồng ngực lựa chọn khi bắt đầu tiến hành PTNS. Theo tác giả Yim và cs: có 3 điểm khác biệt chính trong PTNS cắt thùy phổi bệnh phổi lành tính so với bệnh phổi ung thư là:[1,8,9]

Không cần kiểm tra cắt sạch tận gốc u (bao gồm cả nạo hạch)

Những thay đổi do viêm nhiễm gây ra có thể gây khó khăn cho bóc tách hơn trong bệnh lý ác tính, đặc biệt khi bóc tách mạch máu phổi.

Nếu trong ung thư: sự gieo rắc tế bào ung thư là nguy cơ khi phẫu thuật, lấy bệnh phẩm thì nhiễm trùng vết thương là nguy cơ trong PTNS bệnh phổi không ung thư.

Trong nghiên cứu của Rovario và cs, ông nhận thấy rằng: PTNS cắt thùy phổi trong bệnh $\mathrm{u}$ lao hay u nấm, sự viêm nhiễm, dính mô làm thay đổi cấu trúc giải phẫu mạch máu, rãnh liên thùy, mặt khác các hạch viêm lớn, dính gây khó khăn bóc tách cho phẫu thuật viên, tăng nguy cơ chảy máu, thất bại của phẫu thuật.[7]

\section{PTNS cắt thùy phổi an toàn}

Mặc dù nguy cơ chảy máu trong PTNS khi bóc tách mạch máu phổi, gây ra nhiều lo lắng cho các phẫu thuật viên, tỷ lệ xảy ra biến chứng này rất thấp. Theo nghiên cứu của tác giả Mc Kenna, 
phẫu thuật mổ mở cắt thùy phổi: có tỷ lệ biến chứng từ $28-38 \%$, tỷ lệ tử vong $1,2-2,9 \%$, trong khi PTNS cắt thùy phổi: tỷ lệ biến chứng thay đổi từ $9-19 \%$, tỷ lệ tử vong: $0,8-1,2 \% \cdot[3,4]$

Trong kinh nghiệm của tác giả Weber: trong PTNS cắt thùy phổi ở bệnh u nấm phổi, sự dính thành ngực, rốn phổi, rãnh liên thùy, hạch là yếu tố quyết định đến sự thành bại, an toàn của phẫu thuật, đòi hỏi sự kiên nhẫn của phẫu thuật viên.[1]. Trong bệnh u nấm phổi, thùy phổi thường bị phá hủy, biến dạng gây khó khăn cho bóc tách mạch máu theo giải phẫu, kéo dài thời gian phẫu thuật. Mặt khác do phổi bệnh lý nên biến chứng dò khí thường gặp sau phẫu thuật hơn so với bệnh lý phổi ung thư.[9]

Gossot và cs báo cáo 15 trường hợp u nấm được phẫu thuật, tác giả cho rằng PTNS có nhiều thuận lợi cho bệnh nhân có tổng trạng kém không chịu đựng phẫu thuật mổ mở, ngay cả khi cắt thùy phổi cho bệnh nhân [9]. Whitson và cs báo cáo 20 bệnh nhân được PTNS cắt phổi không điển hình kèm u nấm cho thấy kết quả rất tốt, bệnh nhân hài long, không có tai biến hay tái phát

Ichinose PTNS cho 20 bệnh nhân u nấm phổi, tác giả nhận thấy trong nhóm bệnh nhân $\mathrm{u}$ nấm phổi phức tạp (14 bệnh nhân) có thời gian phẫu thuật dài hơn, máu mất nhiều hơn so với nhóm u nấm đơn giản và có 1 bệnh nhân tử vong sau đó. Bệnh nhân tử vong là bệnh nhân lớn hơn 70 tuổi, bệnh nhân hồi phục sau phẫu thuật không tốt và tử vong do viêm phổi sau đó. Tác giả cũng cho rằng ở những bệnh nhân được thuyên tác đm phế quản trước mổ do ho ra máu sẽ giúp cho giảm sự chảy máu khi $\mathrm{PT}$ gỡ dính vì các mạch máu nuôi đi trong những chỗ dính thành ngực sẽ giảm đi. [9]

Trong nghiên cứu của chúng tôi, tuy số liệu còn ít, nhưng tỷ lệ biến chứng hầu như không đáng kể: 2 bệnh nhân (11.1\%) bị tràn khí dưới da sau mổ, 1 bệnh nhân $(5.5 \%)$ bị chảy máu từ đường mổ đặt trocar sau mổ, được mổ cầm máu qua nội soi, 2 bệnh nhân bị dò khí kéo dài, khí ra dẫn lưu ssau mổ hơn 5 ngày đến ngày thứ 7 mới lành. Hai bệnh nhân (11.1\%) chuyển mổ mở, trong đó một bệnh nhân bị chảy máu khi bóc tách động mạch thùy phổi phải chuyển qua mổ mở để cầm máu, một bệnh nhân do hạch dính sát động mạch cho thùy phổi, không bóc tách được phải chuyển mổ mở. Tất cả bệnh nhân đều ổn định, xuất viện. Không có bệnh nhân nào tử vong trong nghiên cứu của chúng tôi.

Vì vậy, PTNS có thể thực hiện thành công và an toàn cho những trường hợp $\mathrm{u}$ nấm phổi đon giản mà không có dính hay xâm lấn vào rốn phổi, khi bệnh nhân có hạch cạnh rốn phổi thì việc bóc tách mạch máu cũng như phế quản gần hạch rất khó khăn, chúng ta phải cẩn thận vì có nguy cơ tổn thương mạch máu, khi cần thiết chúng ta cũng có thể chuyển mổ mớ.

Trong nghiên cứu của chúng tôi: Ngày nằm viện sau mổ trung bình là 4.2 ngày. Trường hợp bệnh nhân nằm viện lâu nhất là bệnh nhân bị dò khí: 7 ngày. Đa số bệnh nhân được rút dẫn lưu vào ngày hậu phẫu thứ 2 . Lượng máu mất trung bình khoảng $79.6 \mathrm{ml}$, thời gian mổ trung bình 3.1 giờ không quá lâu so với mổ mở.

\section{KẾT LUẬN}

PTNSLN là phương pháp phẫu thuật an toàn, có nhiều ưu điểm, có thể chỉ định trong bệnh u nấm phổi, chủ yếu là u nấm đơn giản. Đối với u nấm phức tạp, phẫu thuật mổ mở vẫn còn lá phương pháp được lựa chọn, PTNS chỉ nên được tiến hành khi PTV có đủ kinh nghiệm và kỹ năng cần thiết để tiến hành PTNS.

\section{TÀI LIỆU THAM KHẢO}

1. Alberto Weber, Uz Stammberger, Ilhan Inci, Ralph A. Schmid, AndreÂ Dutly, Walter Weder* (2001) Thoracoscopic lobectomy for benign disease: a single centrestudy on 64 cases. 
European Journal of Cardio-thoracic Surgery 20; $443-448$.

2. Scott J Swanson and Hasan F Batirel. (2002) Video-assisted thoracic surgery (VATS) resection for lung cancer. The surgical clinics of North America, p 541-561

3. Robert J Mc Kenna, Jr, MD.(2007). Anatomic pulmonary Resections by videoassisted Thoracic surgery. Advanced theraphy in thoracic surgery, p68-74

4. Robert J. McKenna Jr.(2005). VideoAssisted Thoracic Surgery for Wedge Resection, Lobectomy, and Pneumonectomy. General Thoracic Surgery, p524 -532

5. Raja M. Flores and Naveed Z. Alam (2007). Video-Assisted Thorascopic Surgery. Major Lung Resections. Difficult decision in thoracic surgery, p 140 -146

6. Thomas J. Kirby, Brian P Priest (1994). Video assisted thoracoscopic lobectomy. Atlas of video-assisted thoracic surgery. p221-226.
7. Giancarlo Roviaro, Federico Varoli, Carlo Rebuffat, Contardo Vergani, Silvio Marco Scalambra, And Marco Maciocco.(1994) Video thoracoscopic lobectomy and pneumonectomy. Atlas of video-assisted thoracic surgery. 226-236.

\section{Farid Gharagozloo, MD, Barbara} Tempesta, MS, Marc Margolis, MD and E. P Alexander, MD. (2003).Video-Assisted Thoracic Surgery Lobectomy for Stage I Lung Cancer. Ann Thorac Surg.;76:1009 - 15.

9. Peng Zhang, MD, PhD, Fujun Zhang, MD, Siming Jiang, MD, Gening Jiang, MD, Xiao Zhou, MD, Jiaan Ding, MD, and Wen Gao, MD.(2011) Video-Assisted Thoracic Surgery for Bronchiectasis. Ann Thorac Surg.;91:239-43

\section{Junji Ichinose*, Tadasu Kohno,} Sakashi Fujimori. (2010). Video-assisted thoracic surgery for pulmonary aspergilloma. Interactive CardioVascular and Thoracic Surgery 10. 927-930. 